\title{
Design of Temperature and Humidity Monitoring System for Drying and Storage of Allium Ascalonicum L. (Onion)
}

\author{
Irma Saraswati*, Abdul Rahman, Heri haryanto, and \\ Alimuddin \\ Electrical Engineering \\ University of Sultan Ageng Tirtayasa \\ Cilegon, Indonesia \\ *irma.saraswati@untirta.ac.id, abdul.elektro@gmail.com, \\ elektrojos@yahoo.com and alimuddin@untirta.ac.id
}

\begin{abstract}
These instructions give you the Onion is a basic necessity of the community and the food industry, but sometimes it is constrained / crisis due to unbalanced inventory, market needs and causes fluctuating prices. The manufacture of a drying and storage device with temperature and humidity monitoring and thermo electric cooler (TEC) applications is expected to help and accelerate the handling of onions. TEC can produce hot and cold temperatures, then applied to the heating and air conditioning that work simultaneously. Heating serves as a medium of onion drying that works on a set of $370 \mathrm{C}$ temperature and $30-35 \%$ RH humidity. The air conditioner serves as a storage and preserving medium of onion that works on the $250 \mathrm{C}$ temperature set point and $70 \% \mathrm{RH}$ moisture. The testing process is done by monitoring at how much influence the system built on the onion. The results of testing tool on shallots on the drying process for 2 days of red onion shrank $2.6 \%$ mass. Then on the process of storage for 10 days of red onion experienced $8.6 \%$ mass shrinkage and the condition of onion still looks fresh. While on the conventional process when drying onion with drying for 3 days of red onion mass shrinkage of $11.3 \%$. In the storage process in a regular room for 10 days with a temperature condition of $290 \mathrm{C}$ and $68 \%$ humidity of RH onion has a mass shrinkage of $12.2 \%$ and decay occurs on the onion tuber.
\end{abstract}

Keywords: Onion, Thermo Electric Cooler, TEC, Temperature, Humidity.

\section{INTRODUCTION}

Onion is an important commodity for the needs of the community and the food industry. But the circumstances of the onion often experience a crisis that causes fluctuating market prices. This is because the amount of onion inventory in the market is not proportional to market demand. Red onion has a garden period to harvest 50-55 HST (day after planting) then through the drying process is quite time-consuming because it is done through drying under the sun, and often experience obstacles when facing the weather that is not no sun or cloudy until the rain and will be more difficult when it comes to the rainy season. Then after the drying done cleaning and sorting until the next distributed or can be stored for supplies. Each process through which the onion will always experience

\author{
Untung Mardono \\ Mechanical Engineering \\ University of Mercu Buana, Jakarta, Indonesia \\ University of Sultan Ageng Tirtayasa \\ Cilegon, Indonesia \\ u_mardono@yahoo.co.id,
}

shrinkage on the weight / mass and there is the possibility of damage such as the growth of shoots and decay. Based on the journals studied onion will experience mass shrinkage reaches $25-40 \%$ during drying and return loss of mass up to $17 \%$ during storage process. Onion drying process can be done for 7-9 days, if using instore drying at $38^{\circ} \mathrm{C}$ and $55-70 \% \mathrm{RH}$ [1]. But on one farm in Cilegon drying is only done 2-3 days, whereas if using instore drying also takes 2-3 days at $37 \mathrm{oC}$. While the storage process can be carried out at some temperature conditions $25-30 \mathrm{oC}, 10 \mathrm{oC}, 5 \mathrm{oC}$, and at $0 \mathrm{oC}$, and humidity conditions at $65-70 \%$ RH [2] [3].

Thermo electric cooler (TEC) is a technology made of solid-state material (P-type material) of semi-conductor P-type and N-type and has the ability to convert between two forms of energy, namely electrical energy and thermal energy. The ability to convert from a potential electric difference to a temperature difference is called a peltier effect. While on the contrary, the ability to convert from a temperature difference to a different electric potential is called the seebeck effect. Since there have been several studies that have been discussed about the TEC, especially in the university sultan ageng tirtayasa. For example, the first study entitled "Designing Termoelectric Module Using Peltier" by M. Rifa discussing the use of TEC as an electric generator [4]. Then a second study conducted by Nurul Iman with the title "Design Build Portable Auto Cooler by Using Low Power Consumption" in the study discusses the use of TEC as air conditioning [5]. These studies have been conducted using 8 TECs.

After seeing that TEC which is a small and simple component but has many benefits in its application, the researchers took the initiative to conduct research using TEC and apply it into something useful. That is, making the TEC as a cooling device and heating device simultaneously by utilizing the effect of differences in hot and cold temperatures generated on the sides of the TEC. By utilizing TEC capability and applied to cooling and heating apparatus is expected to be used for onion farming especially at the time of processing ahead of harvest in accelerating drying process by using heater 
and can maintain quality of onion during storage process through refrigeration so as to keep onion inventory red to back up market needs. This research describes the manufacture of cooling and heating equipment using TEC and supported by monitoring system so that the condition of temperature and humidity in the room can be monitored and kept under control. There are 8 TECs combined with heatsink, coldsink, and fan so TEC can work well. Coldsink on the cold side of the TEC will be a cooling device because it is tasked to lower the temperature in the cooling/storage room, while the heatsink on the hot side of the TEC will become a heater because it is in charge of releasing the heat absorbed by coldsink and TEC and then the heat is exhaled into the heater/dryer room to raise temperature in the room.

So, based on the above description, the authors compiled research on "Design of Temperature and Humidity Monitoring System for Drying And Storage Allium Ascalonicum L. (Red Onion)".

\section{RESEARCH METHODS}

In this study discussed the design of temperature monitoring and humidity monitoring system for drying and storage of allium ascalonicum 1 (onion), so in this study design and design the refrigerant as storage media and heater as a drying medium.

This cooling and heating system use thermo electric cooler TEC as its main component. TEC has the ability to effect temperature differences that can produce cold temperatures and hot temperatures on each side so that researchers have the idea to use these abilities. The cooling tool aims to make the red onion has a much longer shelf life and better than the traditional storage process. The heater aims to facilitate the process of drying the onion, especially in the curing process (healing of onions) when the harvest. Traditionally curing is done by drying under the sun's heat, but the process can be inhibited if the weather does not support, then with the heater can occur drying without having constrained the weather.

To achieve the purpose of the study required several stages for the research process can run well and structured. The following stages consist of:

\section{A. Preparation and design of tools}

\section{1) Hardware}

a. Body and tool framing

b. Preparation and installation of thermo electric cooler (TEC)

c. Installation of humidifier

d. Installation of components

2) Software

Creation of Arduino program to support the tool working system

B. Testing
Testing thermo electric cooler and humidifier to determine the performance of its ability.

1) Designing Research Tools: In this study, the process through the stages with the block diagram as follows:

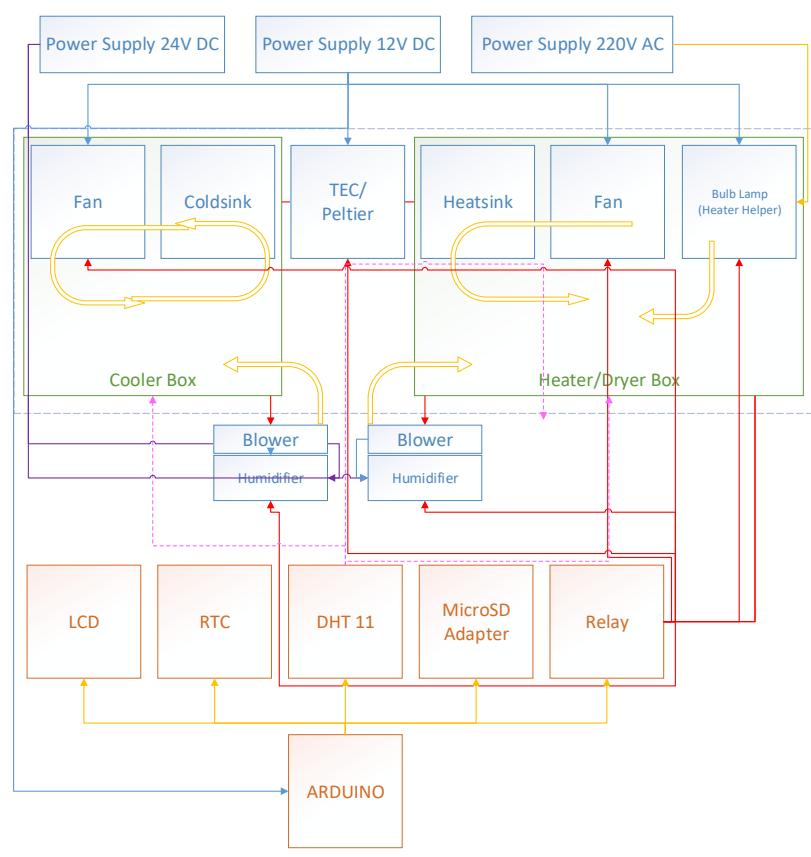

Figure 1. Block Diagram of Research

In the design of cooling and heating equipment using 8 pieces of thermo electric cooler (TEC). TEC is assisted by coldsink and the fan will absorb the heat so as to lower the temperature in the room, while the heatsink will receive heat and release it to the other room (heater) so that the temperature in the room will rise, besides heat incandescent lamps also help increase the room temperature.

Humidity or humidity in each room will decrease during the tool work, so to increase the amount of humidity is helped by humidifier and blower. The humidity level in the room will come back when receiving the moisture fogging results by the humidifier. 


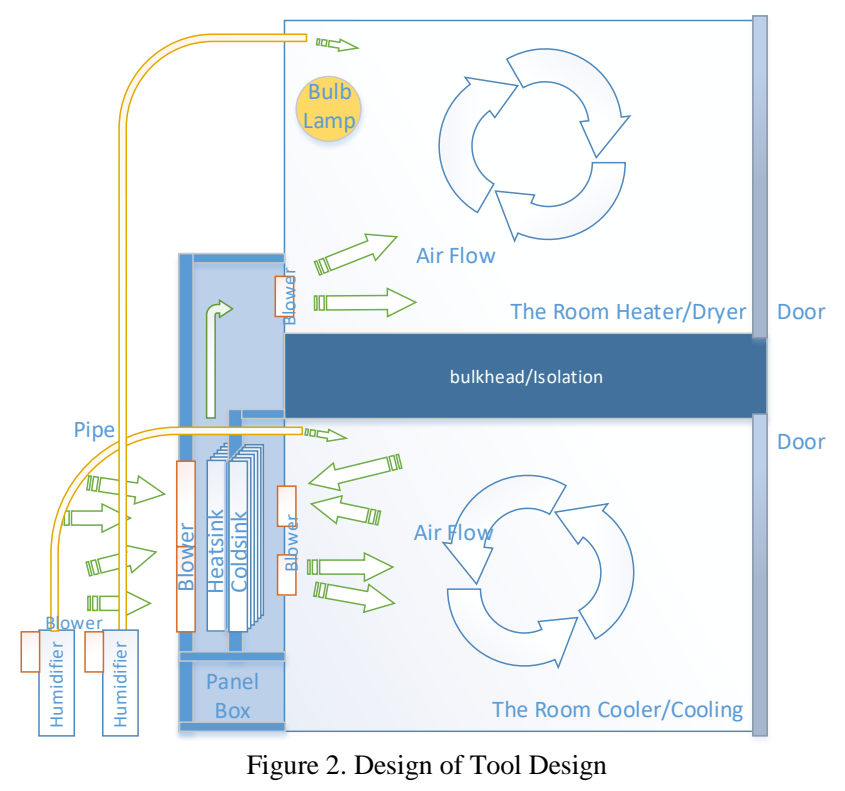

While the arduino component is in charge of controlling each of the connected components as shown in Figure 1. In this system the DHT11 sensor will read the temperature and humidity of each room so that the arduino can provide followup action by controlling the relays connected with TEC, incandescent lamps, and humidifiers.

\section{2) Thermo Electric Cooler (TEC):}

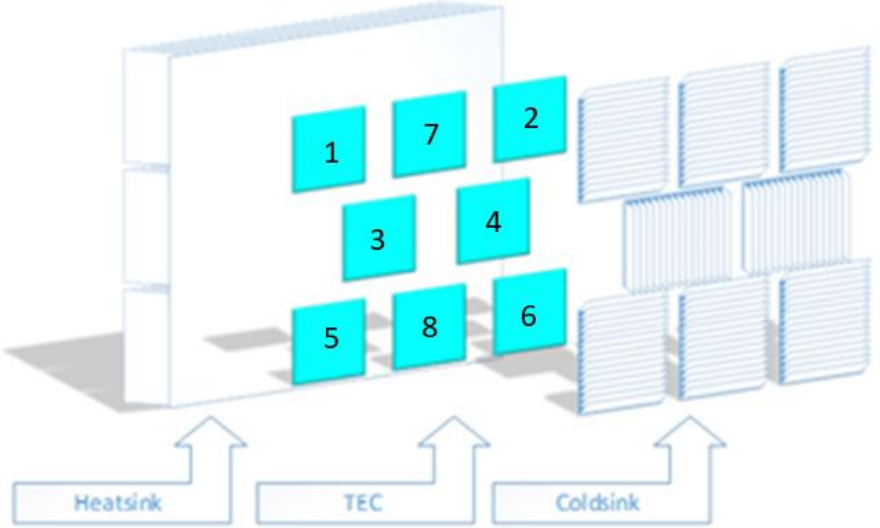

Figure 3. Installation of Heatsink, TEC, and Coldsink

Thermoelectric cooler (TEC) is the most important component in this research tool. Because it is used to decrease and increase the room temperature. The 8 thermo electric cooler (TEC) will be combined with 1 heatsink with a large size, and 8 small coldsinks.

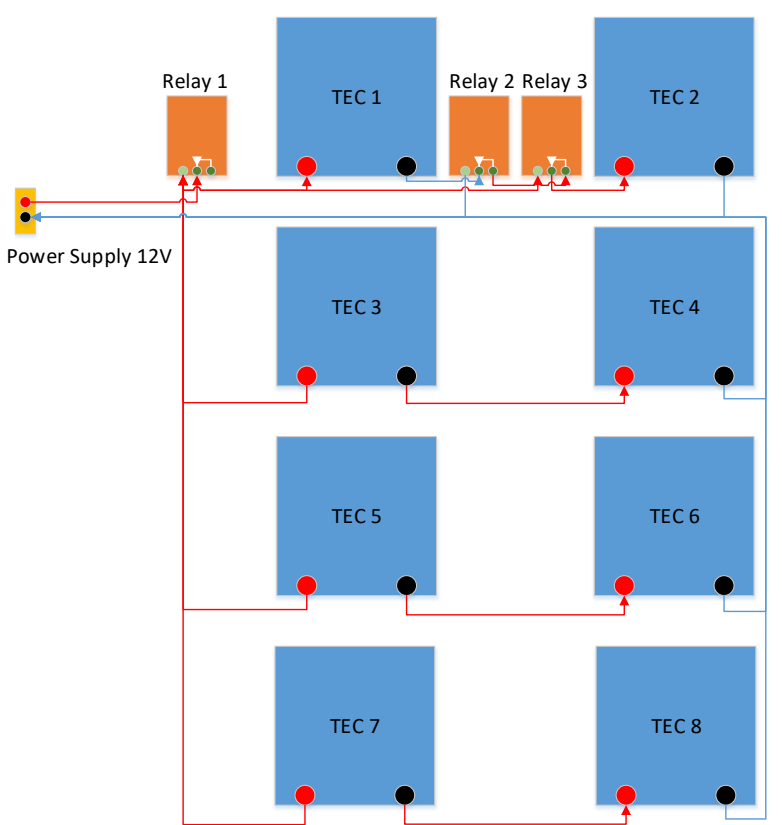

Figure 4. Wiring Thermo Electric Cooler (TEC)

The order of installation of heatsink, thermo electric cooler (TEC), and coldsink by using the prepared frame. After installing all then install the wiring of thermo electric cooler (TEC) with the order of installation as shown in Figures 3 and 4. All thermo electric cooler (TEC) red cable $(+)$ connected to relay 1 , thermo electric cooler (TEC) 1 and 2 will be connected to relays 2 and 3. The wiring is intended to allow the arduino to alter or control the TEC array assembly system. So, the arrangement of the TEC series will easily turn into a series of combinations 2-2-2-2, 1-1-2-2-2, or 1-2-2-2.

3) Humidifier

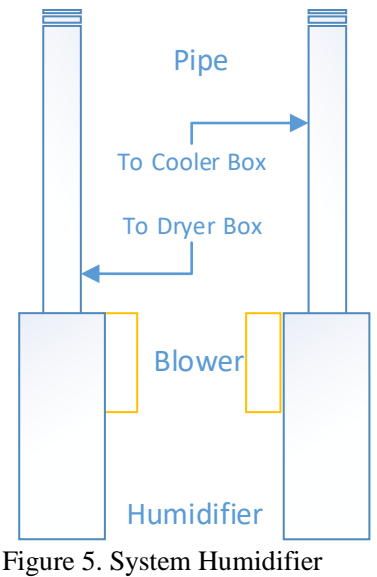

At the time the tool run will cause the humidity will gradually decrease both in the cooling chamber and the space heater. So, to raise it again required a tool of foging or humidifier to increase the number of points of water in the air. Figure 3.25 illustrates the design of a tool consisting of humidifiers and blowers that work to meet the humidity 
requirements of the cooling or heating chamber. Humidifier will make the water in the container into a mist of steam, then blower will push the fog into the room through a hose in the form of a hose that connects the humidifier with the room. In this design use 2 humidifier tools that work for each room.

4) Arduino Mega: Arduino mega as the brain of the processor and controller of the system working on this research tool. All components will be connected to the Arduino so that the Arduino can perform its tasks well. 6 DHT11, RTC, microSD adapters, LCD, and relay sensors directly connected to Arduino pins with pin divisions as described in Figure 3.31 and wiring tables on each of the components previously described.

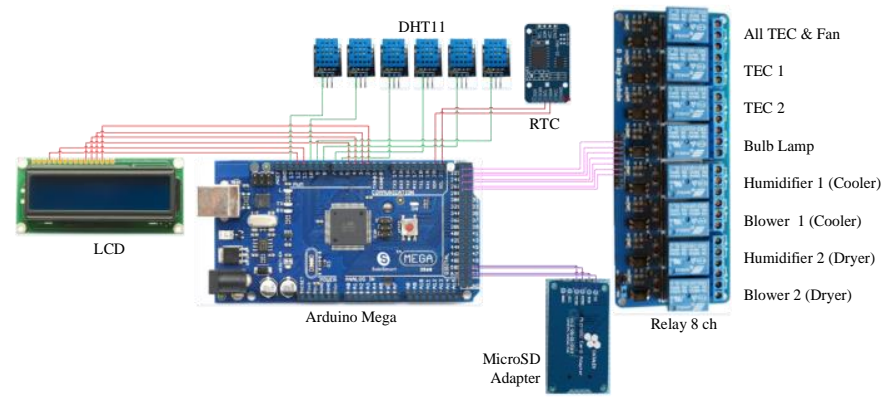

Figure 6. Arduino Wiring Diagrams

\section{RESULTS AND DISCUSSION}

A. Testing Cooling and Heating System

1) Testing Cooling Room: In the cooling chamber testing is done by using several series of TEC arrangement.

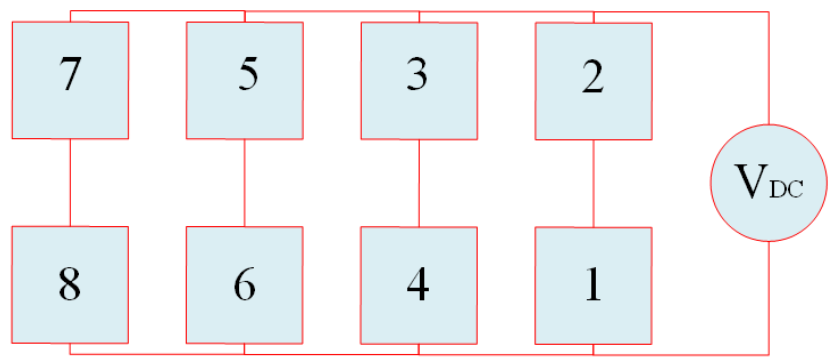

Figure 7. TEC Series 2-2-2-2

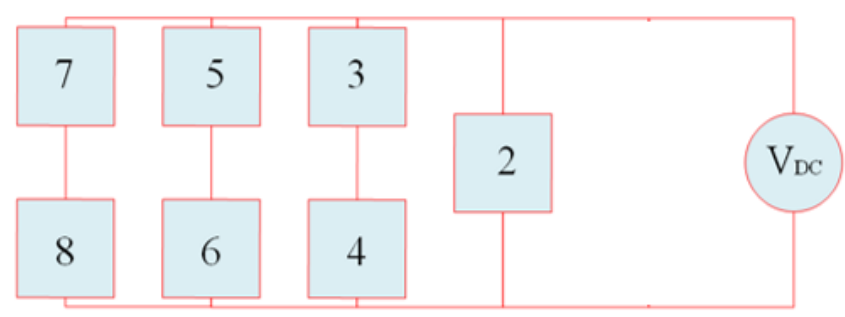

Figure 8. TEC Series 1-2-2-2

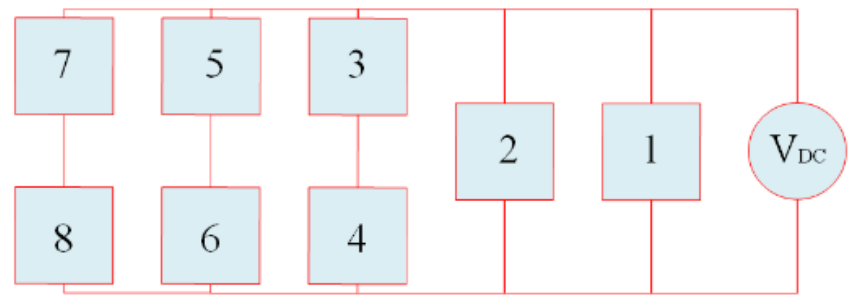

Figure 9. TEC Series 1-1-2-2-2

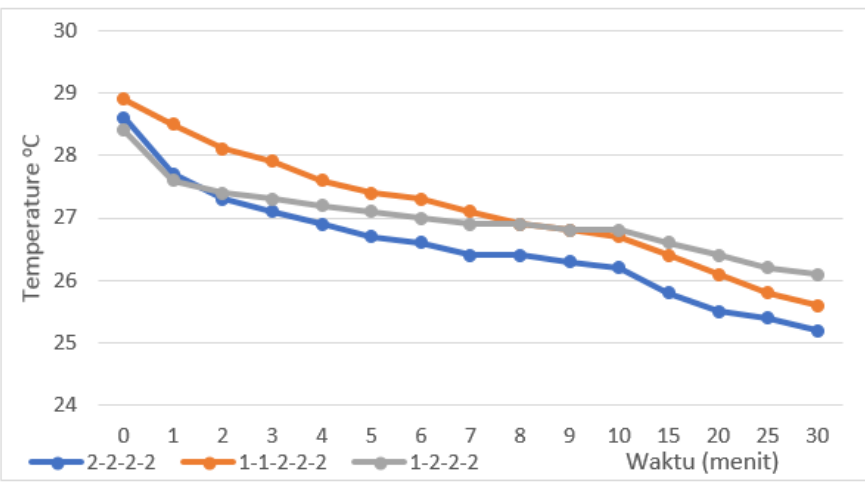

Figure 10. Comparison Graph of temperature at cooler box

TABLE I.

Test CoOling System Temperature With Tec Combination

\begin{tabular}{cccc}
\hline Time (Minute) & $2-2-2-2$ & $1-1-2-2-2$ & $\begin{array}{c}1-2- \\
2-2\end{array}$ \\
\hline 0 & 28,6 & 28,9 & 28,4 \\
\hline 1 & 27,7 & 28,5 & 27,6 \\
\hline 2 & 27,3 & 28,1 & 27,4 \\
\hline 3 & 27,1 & 27,9 & 27,3 \\
\hline 4 & 26,9 & 27,6 & 27,2 \\
\hline 5 & 26,7 & 27,4 & 27,1 \\
\hline 6 & 26,6 & 27,3 & 27,0 \\
\hline 7 & 26,4 & 27,1 & 26,9 \\
\hline 8 & 26,4 & 26,9 & 26,9 \\
\hline 9 & 26,3 & 26,8 & 26,8 \\
\hline 10 & 26,2 & 26,7 & 26,8 \\
\hline 15 & 25,8 & 26,4 & 26,6 \\
\hline 20 & 25,5 & 26,1 & 26,4 \\
\hline 25 & 25,4 & 25,8 & 26,2 \\
\hline & & &
\end{tabular}




\begin{tabular}{cccc}
\hline 30 & 25,2 & 25,6 & 26,1 \\
\hline$\Delta \mathrm{T}$ & 3,4 & 3,3 & 2,3 \\
\hline
\end{tabular}

2) Testing Heating Room: In space heater testing was performed using a 2-2-2-2 TEC circuit and combined with several incandescent lamps.

Table II.

MEASUREMENT OF TEC HEATING TEMPERATURE AND INCANDESCENT LAMP TEC Heater

\begin{tabular}{ccccc} 
& \multicolumn{4}{c}{ Time } \\
\cline { 2 - 5 } & $\begin{array}{c}\text { Lamp } \\
5 \mathrm{~W}\end{array}$ & $\begin{array}{c}\text { Lamp } \\
10 \mathrm{~W}\end{array}$ & $\begin{array}{c}\text { Lamp } \\
25 \mathrm{~W}\end{array}$ & $\begin{array}{c}\text { Lamp } \\
60 \mathrm{~W}\end{array}$ \\
\hline 0 & 29,1 & 27,9 & 28,7 & 28,3 \\
\hline 1 & 29,5 & 28,8 & 30,4 & 31 \\
\hline 2 & 30 & 29,2 & 31,3 & 32 \\
\hline 3 & 30,2 & 29,4 & 31,5 & 33,1 \\
\hline 4 & 30,5 & 29,9 & 32 & 34 \\
\hline 5 & 30,5 & 30,2 & 32,2 & 34,3 \\
\hline 6 & 30,9 & 30,8 & 32,3 & 35,5 \\
\hline 7 & 31 & 30,9 & 32,6 & 35,6 \\
\hline 8 & 31,2 & 31,4 & 32,8 & 36 \\
\hline 9 & 31,1 & 31,6 & 33 & 36,3 \\
\hline 10 & 31,5 & 31,6 & 33 & 36,6 \\
\hline$\Delta \mathrm{T}$ & 2,4 & 3,7 & 4,3 & 8,3 \\
\hline & & & &
\end{tabular}

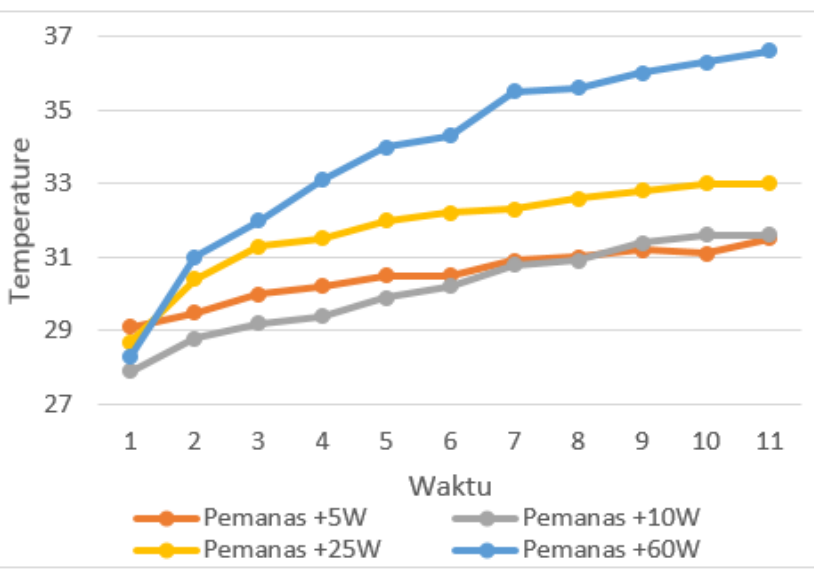

Figure 11. Temperature Graph of Using TEC and Incandescent Lamp

\section{B. Testing of Loading}

\section{1) Testing without the loads}

TABLE III.

TESTING OF NON-LOAD SYSTEM Cooler Heater

\begin{tabular}{ccccc}
\hline & \multicolumn{2}{c}{ Cooler } & \multicolumn{2}{c}{ Heater } \\
\hline No & Temp $^{\circ} \mathrm{C}$ & Humd $\%$ & Temp $^{\circ} \mathrm{C}$ & Humd $\%$ \\
\hline 0 & 30,2 & 88,5 & 31,3 & 88,4 \\
\hline 1 & 27,5 & 88,5 & 37,5 & 55 \\
\hline 2 & 26,5 & 80,5 & 40,5 & 41 \\
\hline 3 & 26,5 & 82,5 & 40,5 & 40 \\
\hline 4 & 26,5 & 81 & 40 & 40,5 \\
\hline
\end{tabular}

\begin{tabular}{ccccc}
\hline 5 & 24,5 & 79,5 & 42,5 & 42 \\
\hline 6 & 24,5 & 81 & 40,2 & 43 \\
\hline
\end{tabular}

2) Testing with the load of water

TABLE IV

SySTEM TESTING WITH THE LOAD OF WATER

\begin{tabular}{ccccccc}
\hline No & \multicolumn{2}{c}{ Cooler } & \multicolumn{2}{c}{ Heater } & \multicolumn{2}{c}{ Temperature of Water } \\
\hline & Temp & Humd & Temp & Humd & Cooler & Heater \\
\hline 1 & 28,5 & 87 & 32 & 71,5 & 26,8 & 28 \\
\hline 2 & 25 & 83 & 41,5 & 35,5 & 26,1 & 31,5 \\
\hline 3 & 25,5 & 81,5 & 41 & 32,5 & 25,8 & 32,7 \\
\hline 4 & 25,5 & 82 & 40,5 & 32,5 & 25,6 & 32,1 \\
\hline 5 & 25,5 & 81 & 40 & 32 & 25,6 & 33,5 \\
\hline 6 & 25,5 & 80,5 & 40,5 & 32 & 25,4 & 33,8 \\
\hline 7 & 25,5 & 80,5 & 41,5 & 32,5 & 25,3 & 33,5 \\
\hline 8 & 25,5 & 81,5 & 40,5 & 32,5 & 25,2 & 33,1 \\
\hline
\end{tabular}

3) Testing with Red Onion Burden

TABLE V

DRYING OF CONVENTIONAL ONIONS

\begin{tabular}{cccccccc}
\hline \multirow{2}{*}{ No } & \multirow{2}{*}{$\mathrm{H}$} & \multicolumn{2}{c}{$\mathrm{H}+1$} & \multicolumn{2}{c}{$\mathrm{H}+2$} & \multicolumn{2}{c}{$\mathrm{H}+3$} \\
\cline { 3 - 8 } & & Mass & Shrink & Mass & Shrink & Mass & Shrink \\
\hline 1 & 300 & 266 & -34 & 241 & -25 & 227 & -14 \\
\hline 2 & 300 & 265 & -35 & 237 & -28 & 221 & -17 \\
\hline
\end{tabular}

TABLE VI

DRYING OF ONIONS WITH DRYER

\begin{tabular}{cccccc}
\hline \multirow{2}{*}{ No } & \multirow{2}{*}{$\mathrm{H}$} & \multicolumn{2}{c}{$\mathrm{H}+1$} & \multicolumn{2}{c}{$\mathrm{H}+2$} \\
\cline { 3 - 6 } & & Mass & Shrink & Mass & Shrink \\
\hline 1 & 300 & 268 & -32 & 260 & -8 \\
\hline 2 & 300 & 262 & -38 & 252 & -10 \\
\hline 3 & 300 & 260 & -40 & 249 & -11 \\
\hline
\end{tabular}

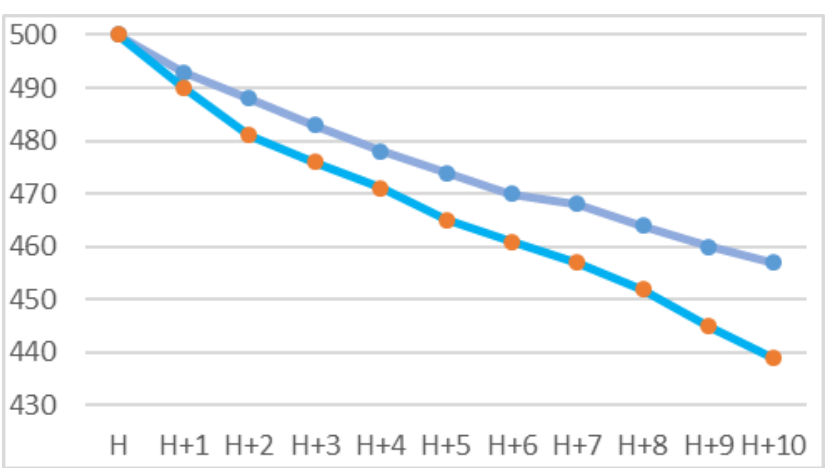

Figure 12. Comparison Chart of Conventional Drying with Dryer 
TABLE VII

CONVENTIONAL ONION STORAGE

\begin{tabular}{ccc}
\hline Day & Mass (gram) & Shrinkage (gram) \\
\hline $\mathrm{H}$ & 500 & - \\
\hline $\mathrm{H}+1$ & 490 & -10 \\
\hline $\mathrm{H}+2$ & 481 & -9 \\
\hline $\mathrm{H}+3$ & 476 & -5 \\
\hline $\mathrm{H}+4$ & 471 & -5 \\
\hline $\mathrm{H}+5$ & 465 & -6 \\
\hline $\mathrm{H}+6$ & 461 & -4 \\
\hline $\mathrm{H}+7$ & 457 & -4 \\
\hline $\mathrm{H}+8$ & 452 & -5 and rotten \\
\hline $\mathrm{H}+9$ & 445 & -7 and rotten \\
\hline $\mathrm{H}+10$ & 439 & -6 \\
\hline
\end{tabular}

TABLE VIII

THE ONION STORAGE WITH COOLER

\begin{tabular}{ccc}
\hline Day & Mass (gram) & Shrinkage (gram) \\
\cline { 2 - 3 }$H$ & 500 & - \\
\hline $\mathrm{H}+1$ & 493 & -7 \\
\hline $\mathrm{H}+2$ & 488 & -5 \\
\hline $\mathrm{H}+3$ & 483 & -5 \\
\hline $\mathrm{H}+4$ & 478 & -5 \\
\hline $\mathrm{H}+5$ & 474 & -4 \\
\hline $\mathrm{H}+6$ & 470 & -4 \\
\hline $\mathrm{H}+7$ & 468 & -2 \\
\hline $\mathrm{H}+8$ & 464 & -4 \\
\hline $\mathrm{H}+9$ & 460 & -4 \\
\hline $\mathrm{H}+10$ & 457 & -3 \\
\hline
\end{tabular}

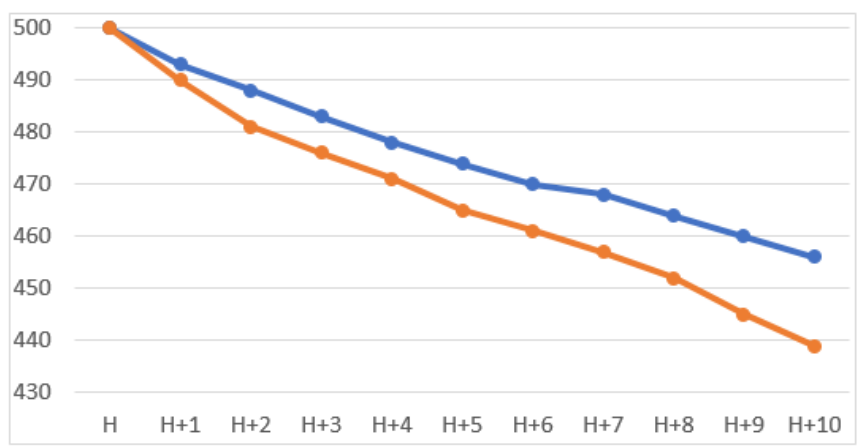

Figure 13. Comparison Chart of Conventional Storage with Cooler

\section{CONCLUSION}

\section{A. Conclusions}

The research has reached the end and obtained the following conclusions:

1) In this research successfully applied peltier effect capability of thermo electric cooler in generating hot and cold temperature difference, on cold side of TEC used in refrigeration room or cooler as cooling chamber and preservation media, while on hot side of TEC used in space heater or dryer as a space heater and drying medium.

2) In this study using 8 pieces of TEC 12706 are arranged in combination 2-2-2-2, 1-2-2-2, and 1-1-2-2-2. The use of the 2-2-2-2 circuit is used because the circuit is quite easy and fast in lowering the room temperature and the temperature is also quite stable and the power used TEC is not large only $72.31 \mathrm{~W}$.

3) Comparison of onion conditions after storage, on the use of cooler onions look brighter colors, shrinkage is smaller only 43 grams whereas with no cooler or conventional way of shrinking 61 grams and decay occurs 2 tubers of red onion.

4) Comparison of post-harvest post-harvest onion process using faster dryers achieved, and shrinkage was less that 40 grams compared with the process using conventional drying method experienced a shrinkage of 73 grams.

5) Cooler conditions are at $25^{\circ} \mathrm{C}$ and $70 \%$, while the dryer is at $37^{\circ} \mathrm{C}$ and $35 \%$.

\section{B. Suggestion}

In this study experiencing constraints in the construction of the tool so that the results of this study still need action of perfecting and improvements. Based on the constraints experienced can be given suggestions for further research:

1) The use of materials in this study using wood plywood. Wood plywood has advantages in the ease of designing the tool form and the cheap price, but has a deficiency in terms of the effect of possibility of porous or weathered and the influence on the performance of TEC because the temperature may be absorbed by wood plywood but this has been minimized by coating using styrofoam, and aluminum foil on the frame.

2) Temperature produced by TEC is still limited to only about $25^{\circ} \mathrm{C}$ if it can be lower will have better preservation effect.

3) DHT11 sensor can be replaced with other sensors because the sensor is less sensitive in reading and should be often calibrated because sometimes the reading is going far enough.

\section{REFERENCES}

[1] Fitria, Eka. Teknik Pengeringan Untuk Meningkatkan Mutu Bawang Merah Di Provinsi Aceh.

[2] Nurkomar, rakhmadion S, Kurnia L. Teknik Penyimpanan Bawang Merah Pasca Panen Dijawa Timur. 2001, Jurusan Teknologi Pertanian.

[3] Mutia. A Khairun, Purwanto. Y Aris, Pujantoro. Litik. Perubahan Kualitas Bawang Merah (allium Ascalonicum L.) Selama Penyimpanan Pada Tingkat Kadar Air dan Temperatur yang Berbeda. Departemen Teknik Mesin dan Biosistem. Institut Pertanian Bogor

[4] Makhsum, M. Rifa. Perancangan Modul Termoelektrik Generaotr Menggunakan Peltier. 2014 Universitas Sultan Ageng Tirtayasa. Cilegon

[5] Iman, Nurul. Rancang Bangun Pendingin Portable Otomatis dengan Menggunakan Konsumsi Daya Rendah. Universitas Sultan Ageng Tirtayasa. Cilegon 
[6] Tulak, Alden. Teg Dengan 7 Termoelektrik Rangkaian Seri Untuk Charger Handphone Pendingin Kabin Mobil Berbasis Termoelektrik. 2013, Universitas Sanata Dharma. Yogyakarta.

[7] Priyambada, Sandya. Pendingin Kabin Mobil Berbasis Termoelektrik. 2012, Universitas Indonesia. Depok.

[8] DH., Shepta. Rancang Bangun Sistem Pengukuran Efisiensi Sel Peltier Berbasis Microkontroler. 2012, Universitas Indonesia. Depok.

[9] Umboh. R, Wuwung. J.O., Allo. E. Kendek, Narasiang. B.S. Perancangan Alat Pendinginan Portable Menggunakan Elemen Peltier. UNSRAT. Manado

[10] Datasheet Thermo Electric Cooler TEC1-12706

[11] Akmaludin, Dzulfikar. Prototipe Rumah Jamur Merang Otomatis Dengan Pengendali Suhu Dan Kelembaban Menggunakan Mikrokontroller Atmega8535. 2014, Sekolah Tinggi Manajemen Informatika Dan Komputer Amikom. Yogyakarta.

[12] Datasheet Mist Maker Humidifier Ultrasonic 24V

[13] Alfianto. Hendry, Analisis Penawaran Bawang Merah di Kabupaten Karanganyar. 2009, Univeritas Sebelas Maret. Surakarta.

[14] Juliasari. Noni, Hartanto. Erian Dwi, Mulyati. Sri, Monitoring Suhu Dan Kelembaban Pada Mesin Pembentukan Embrio Telur Ayam Berbasis Mikrokontroler Arduino UNO. 2016, Universitas Budi Luhur. Jakarta

[15] Pradipta. Gagat Mughini, Pembuatan Prototipe Sistem Keamanan Laboratorium Berbasis Arduino Mega. 2016, Universitas Negeri Jakarta

[16] Supriyono, Pemantau Temperatur dan Kelembaban Pada Rumah Kaca Berbasis Mikrokontroller ATMEGA 8535. 2001, UNNES

[17] Dirga, Lemari Penyimpanan Berbicara Berbasis Mikrokontroller. 2016, Universitas Sanata Dharma. Yogyakarta

[18] Hindasyah. Achmad, Rancang Bangun Sistem Instrumentasi Elektrokardiogram Dan Aktifitas Gerak Secara Wireless. 2009, Universitas Indonesia. 